\title{
Exploration into Teaching Model of College English Writing in the Big Data Era
}

\author{
Hua Yang \\ College of Foreign Studies, \\ Guilin University of Electronic Technology, \\ Guilin, Guangxi, China \\ 16898559@qq.com
}

\author{
Qiu-ping Huang \\ College of Foreign Studies, \\ Guilin University of Electronic Technology, \\ Guilin, Guangxi, China \\ 122407609@qq.com
}

\begin{abstract}
The purpose of this paper is to explore new ide as to college English writing teaching with the help of modern information technology. This paper introduces the characteristics of big data, and analyzes the problems of conventional college English writing teaching. Then it discusses the influence of big data on college English writing teaching. Finally, the paper presents several proposals to the teaching reform of college English writing in the big data era. The innovation of this paper is that it discusses the impact of big data on college English writing teaching and arouses the new reflection on te aching mode of college Englis h writing.
\end{abstract}

Keywords - big data; information technology; teaching mode; college English writing

\section{INTRODUCTION}

The development and popularization of Internet technology in the 21st century and the emergence of new media have brought human society from the information age into a new era of big data. Big data not only means more information, but also changes the way people behave and even think, which also provides new opportunities for college foreign language teaching. The integration of information technology and education in the era of big data will bring systemic change to foreign language teaching, and meanwhile it will have a profound impact to the teacher's role, students' role, learning materials, learning environment and teaching evaluation and testing and so on. Faced with the challenges and opportunities brought by this new technology to foreign language teaching, foreign language teachers began to pay much attention to many questions, such as the implications of big data methods on foreign language teaching innovation, the composing of English teachers' teaching ability in the big data era, the relationship between big data and MOOCs (including microlectures), and the spread of college English teaching. This paper aims at analyzing the main problems of traditional college English writing teaching based on the environment of big data, and discusses the methods and teaching mode of college English writing teaching reform in the era of big data.

\section{DEFINITION AND CHARACTERISTICS OF BIG DATA}

\section{A. Definition of Big Data}

The term has been in use since the 1990s, with some giving

This work is supported by the Foundation projects: (1)Research on the teaching mode of College English scaffolding writing based on micro-lectures (Guangxi Higher Education Institution Research Project, 2017JGA 202); (2)Research on English writing teaching mode under education engineering background (GUET Science and Education Cooperation Project, CS16027X) credit to John Mashey for coining or at least making it popular. ${ }^{[1]}$ Big data usually includes data sets with sizes beyond the ability of commonly used software tools to capture, curate, manage, and process data within a tolerable elapsed time. ${ }^{[2]}$ Big Data philosophy encompasses unstructured, semi-structured and structured data; however the main focus is on unstructured data. ${ }^{[3]}$ Big data "size" is a constantly moving target, as of 2012 ranging from a few dozen terabytes to many petabytes of data. Big data requires a set of techniques and technologies with new forms of integration to reveal insights from datasets that are diverse, complex, and of a massive scale. ${ }^{[4]}$

A consensual definition states that "Big Data represents the Information assets characterized by such a High Volume, Velocity and Variety to require specific Technology and analytical methods for its transformation into Value". ${ }^{[5]}$

\section{B. Characteristics of Big Data}

Big data can be described by the following characteristics: a) Volume: means the quantity of generated and stored data. The size of the data determines the value and potential insight- and whether it can actually be considered big data or not. This is the most striking feature of big data. b) Variety: refers to the type and nature of the data. This helps people who analyze it to effectively use the resulting insight. c) Velocity: means the speed at which the data is generated and processed to meet the demands and challenges that lie in the path of growth and development. In the age of big data, the transmission speed of information will develop rapidly with the network. d) Value: means using big data reasonably to create high value at low cost.

Big data has increased the demand of information management specialists so much so that Software AG, IBM, Microsoft, SAP, EMC, HP and Dell have spent more than $\$ 15$ billion on software firms specializing in data management and analytics. ${ }^{[7]}$ Research on the effective usage of information and communication technologies for development suggests that big data technology can make important contributions but also present unique challenges to International development. Big data technology brings us not only innovation and convenience, but also a new thinking pattern. In education, big data is quietly changing the way that teachers and students learn. The free and open MOOCs and micro-lectures not only challenge the traditional teaching process, but also reconstruct the new teaching process based on the Internet and give a birth to the 
flipped classroom teaching mode. Educators can obtain students' learning data mainly from online management and curriculum management platforms, get students' learning characteristics and methods by analyzing the tracks of student learning, and hence provide support for teachers to develop personalized teaching.

\section{Problems EXISTING IN TRADITIONAL COLLEGE ENGLISH WRITING TEACHING}

College English Curriculum Requirements (2007) points out the teaching objectives of college English is to cultivate the students' English comprehensive application abilities. For writing, college English students are required to have the abilities to accomplish general writing tasks and master basic writing skills. But unfortunately, although our students have been studying English for several years, English writing ability has not improved significantly. In terms of its reasons, there are many problems, such as unclear writing teaching objectives, lack of teaching resources, poor teaching methods, boring and tedious teaching contents and so on. As a result, writing teaching is not satisfactory.

\section{A. Unclear Teaching Objectives of Writing}

The teaching objectives of English writing teaching in Chinese universities are not clear and they are out of line with the practical application of students' writing. In general, we value the input of knowledge much more and neglect the output of it. The teaching of college English writing is still guided by English test band 4 and 6 . In the class, teachers mainly analyze the writing topics, study the models, explain the structures of the text, and practice the typical sentences and patterns. Students often write for the sake of writing, write for the test, and ignore writing as an application value of productive skills. ${ }^{[8]}$ Teachers pay much attention to cultivate students' linguistic knowledge, and ignore cognitive, emotional and social factors. Students generally believe that English writing is only used in exams. In real life, there are no opportunities to express their thoughts in English. Therefore, the students seldom think about the readability of the article and seldom care the real quality of the writing.

\section{B. Inadequate Teaching Resources of Writing}

Due to the restriction of education resources, the class sizes of Chinese college English courses are generally large, with the minimum average of about 40-60 students, and sometimes even up to 90 students. From the effectiveness of language skills training, the teaching of "speaking" and "writing" has higher requirements for the interaction between teachers and students. In the class with a large number of students to implement writing teaching, the effectiveness of teaching is greatly reduced. For teachers, it is difficult to grasp each student's writing defects, and therefore can't provide specific guidance to every single student. For students, if they can't interact with their teachers in a timely and effective way, they can't realize that writing needs to be remedied and improved. Consequently, the writing level has been stagnant for a long time, thus lose interest in writing. ${ }^{[8]}$

\section{Poor Teaching Methods of Writing}

In traditional college English writing classes, most of the teachers are the dominators. Teachers are usually the initiators of knowledge, fully control students' learning contents, learning processes and learning styles, while students lie in a passive position. There are nearly no interaction between teachers and students especially when they have writing class. Teachers mainly introduce the writing models, typical sentences and patterns and ask the students to follow. Students have no chance to cultivate their own critical thinking, express their thoughts freely, and order their ideas logically. Gradually the students lose the ability to share their own ideas and compose a wellorganized thesis. And finally they have no willingness to participate in learning activities, lack learning initiative and lose interest in writing.

\section{Boring and Tedious Teaching Contents of Writing}

The lack of diverse, targeted, and scientific writing teaching material is one of the significant problems that the writing teachers are confronted with. In writing class, teachers can only take the writing part from the reading and writing textbook. The writing task and training are often designed to cooperate with the reading course. It lacks a systematic explanation of writing skills. Teachers often need to supplement the teaching materials of writing according to their own teaching experience. Meanwhile, it is difficult for teachers to find the proper reading materials for the purpose of practicing writing skills. If students can hardly get adequate and effective language input, it would be difficult for them to accumulate enough and good language expressions in their writing. Finally they would find they have nothing to say when they are writing a composition. In addition, sometimes the writing materials and topics are very tedious and not fashionable or not realistic. They are far away from students' life and don't match the students' current cognition. It is really hard for students to write a composition beyond their perceptions.

Apart from the four problems discussed above, another typical factor is the students' self-learning ability. Students lack the ability to learn independently. After the graduation from high school and entering the college, lots of students spend less energy on learning and become lazy. If there is no strict rules requirements from school, students are not willing to pay much effort to English learning, let alone English writing. So their writing level could not be improved efficiently.

\section{INFLUENCE OF Big DATA ON COLLEGE ENGLISH WRITING TEACHING}

With the coming of the era of information, data has become an important resource in the process of social construction. When enormous data prompts great changes have taken place in various related fields, English writing teaching also presents the new development trend.

\section{A. Influence on Teaching Objectives of Writing}

In the era of big data, the teaching objectives of writing have changed. Teachers can shift teaching objectives of writing from imitating the structure and learning perfect expressions to cultivating students' real writing ability. A lot of Writing 
software and online writing systems emerge in the era of big data. These writing software and on-line authoring auxiliary systems can solve many language problems of learners, enabling the learner to devote more energy to the generation and organization of writing content. With the help of these systems, students could not only learn and imitate the former writing models, memorize the excellent expressions and patterns, but also make it much easier to improve their writing skills. Students can accomplish a writing assignment online, modify the writing many times, then share their wonderful works to the others. In this way, students can be both writers and readers. Because writing will receive the attention of other students, the students' writing has got a real meaning, no longer only the homework assigned by teachers.

Cultivating various abilities of students would be a new objective of teaching in the era of big data during the writing process instead of the single ability of English writing. If the teachers assign the writing task ahead, students can surf the Internet for diverse and relevant materials, categorize the materials, and discuss the materials. Therefore during this process, students have trained their abilities of how to search materials, how to organize materials, how to cooperate with others, how to communicate with others, how to present ideas and so on. And in this way, learning process would be much more meaningful.

\section{B. Influence on Teaching Resources of Writing}

In the age of big data, English writing teaching resources have been greatly enriched. First of all, many writing teaching resources on the Internet provide a lot of guidance. These resources are variable. They are both textual and audio-visual. The learners can easily get both the textual teaching and the real-time classroom video teaching, both the introduction of new content and the practice and testing of the content they have learned; both static teaching content and real-time online interaction between students and students or between students and teachers. In addition, the network provides specialized retrieval tools. In English writing, students can retrieve content related to specific topics and obtain rich and varied writing materials through the Internet. The retrieval tools and search engines can provide information and help in English writing content, vocabulary, collocation, etc. ${ }^{[9]}$

Therefore, it largely makes up for the lack of teaching resources in traditional teaching.

\section{Influence on Teaching Methods of Writing}

Due to the application of computer in college English writing teaching, the teaching method of writing has also changed correspondingly. In the era of big data, teachers not only emphasize on the interpretations and practices in class, but also spend energy and time on the task arrangement, supervision and effect evaluation of the writing study after class with the help of many Internet writing systems or platforms. Compared with traditional poor and boring teaching methods, teachers' teaching methods now become diversified and novel, which can significantly stimulate students' interest in writing practice. For students, they usually no longer use traditional pen and paper to finish writing, but use computer software for writing exercises. As we known, now several
Internet writing platforms are very popular in China, such as http://www.pigai.org. It can provide students with real-time online feedback on vocabulary, grammar and text. And it can help students to use words in the writing process, solve most of the grammar problems, improve the students' ability of language use, and save teachers time to deal with students' language mistakes. ${ }^{[9]}$ The application of these systems greatly reduced the burden of students in the language form and the article format, so that they can put more energy into the generation of content and organization, and eventually improve English writing ability with a more positive attitude toward writing.

So, it can be seen that under the circumstances of big data, English writing teaching method has been optimized accordingly.

\section{Influence on Teaching Contents of Writing}

In a computer network environment one of the advantages of writing teaching is that teaching contents of writing would be implemented a lot. Teachers can retrieve much more content related to specific topics by using certain search engines. They can search lots of materials about writing from the Internet, which would include the traditional basic writing skills such as writing patterns, expressions and writing models and so on. They can also search the newest electronic data, such as the latest academic development academic research, and the newest social hot topics and etc. The use of the Internet has changed the difficulty of finding materials for writing teachers. And all the fresh and well-organized materials will perfect the boring teaching contents in the traditional teaching mode.

In the era of big data, the use of the network enables students to acquire abundant learning resources. And it also provides a way for learners to communicate with each other. Through communication and cooperative learning, students will have more ideas and greater interest in writing. This not only helps the students to collect the writing contents, but also helps the students to think about the overall structure of the article to ensure the logic and integrity of the article. Eventually, it will help the students to write better.

\section{PROPOSALS TO TEACHING REFORM OF COLLEGE ENGLISH WRITING IN THE ERA OF BIG DATA}

Because of the impact from big data, the college English teachers should fully analyze the related influencing factors when we try to explore the new teaching mode in writing teaching process, then develop better coping strategies, then provide good support for the reform and innovation of college English writing teaching. Here, there are several proposals to the teaching mode of college English writing in the era of big data:

\section{A. Integrating Teaching Resources and Contents}

Big data makes the teaching content of college English writing not only confined to classroom, but also extends out of the classroom and extends into cyberspace. Teachers should make full use of the network media, electronic resources and other language acquired channels, so that students have sufficient language immersion. Teachers use the network 
resources to make some information resources, such as MOOCs and mini-lectures, let students practice writing in English, and then understand students' real-time performance through the timely feedback of Internet as follow. At the same time, students can use various search engines to collect, find and analyze information on the Internet, and use various social software such as microblog and E-mail to communicate and express ideas. And they can accurate the writing mistakes and acquire the relevant writing skills by do more reading and more searching on the Internet. If they like, they could have the real-time discussion with the teachers on the writing platform. So, the age of big data provides a good platform for the teaching reform and innovation of English writing in the present stage. It is helpful for university teachers to explore new teaching mode in the process of teaching English writing, which can effectively improve the overall quality of college English writing teaching.

\section{B. Changing Traditional Teaching Mode}

On the basis of existing English teaching, multimedia teaching method could be widely used. In the era of big data, various multimedia teaching methods based on data have already been applied in English teaching, and English teaching has gradually changed into computer teaching mode. In the traditional teaching process, the whole writing process of the students is mainly through their own independent completion, and hand in their work with paper. In the era of big data, teachers can make full use of network resources, and can conduct multimedia teaching in the course of English writing teaching. Students can learn through online learning platforms, communicate with teachers and students on the Internet, and conduct English writing exercises on the basis of network computers. Students can query, collect data over a network, make systematic modification and collection to the articles, and submit the articles through Internet. Teachers also provide feedback on students' compositions through the Internet. In the age of big data, the whole writing process of students is recorded in detail if students write English on the Internet platform. Teachers can understand students' learning status according to their data, find the students' learning rules, achieve targeted teaching, and finally improve students' English writing ability comprehensively.

\section{Improving Teaching Evaluation System}

The writing teaching in the age of big data is inseparable from information technology. Network teaching platform and evaluation system are required in many writing teaching steps, such as, the collecting of writing materials, displaying of various teaching resources, organizing of teaching activities, the handing in of homework, checking and evaluating, interacting of teachers and students online and so on. But now many teaching platforms and evaluation systems are existing in the market. They have their own advantages and disadvantages, and don't cooperate with other. So our teaching sometimes will be confined by some certain defects. In the data era, the teaching platform should be able to integrate different network application systems and functions. And online assist system and evaluation system should be open. The internal and external teaching resources should be integrated in order to provide more scientific, timely and personalized feedback and help to the big data analysis system.

\section{Improving English Teachers' Information Technology Application Ability}

The arrival of the big data era has provided some convenience for college English teaching and has raised higher requirements for the comprehensive quality of English teachers in colleges and universities. ${ }^{[10]}$ In the course of teacher training, it's important to cultivate teachers' information technology application ability. Only in this way can we ensure that teachers can make full use of the advantages of the big data era in the teaching process to reform and innovate the English writing teaching, so as to further improve the teaching quality of English writing.

\section{SUMMARY}

The advent of big data era has brought a certain impact on the traditional college English teaching model, and put forward more strict requirements on the cultivation of English talent pattern and methods. This also provides a new development opportunity for the reform of college English writing teaching. Therefore, in the course of college English writing teaching, on the basis of the development model of big data, we should follow the trend of the times, constantly change our teaching mode, explore the ideas to the modes of college English writing reform, improve the teaching mode of college English writing, and develop a compound applied English talent that can meets the development needs of the times.

\section{ACKNOWLEDGMENT}

I would like to express my heartfelt gratitude to my teammates. They have walked me through all the stages of the writing of this paper.

\section{REFERENCES}

[1] John R. Mashey. 1998. "Big Data and the Next Wave of InfraStress" (PDF)

[2] Snijders, C., Matzat, U.,Reips, U.-D., "'Big Data': Big gaps of knowledge in the field of Internet". International Journal of Internet Science. 2012, 7, pp. 1-5.

[3] Dedić, N., Stanier, C., "Towards Differentiating Business Intelligence, Big Data, Data Analytics and Knowledge Discovery", Berlin, Heidelberg Springer International Publishing,2017.

[4] Ibrahim; Targio Hashem, Abaker; Yaqoob, Ibrar; Badrul Anuar, Nor; Mokhtar, Salimah; Gani, Abdullah; Ullah Khan, Samee (2015). "big data" on cloud computing: Review and open research issues". Information Systems. 47: 98-115.

[5] De Mauro, Andrea; Greco, Marco; Grimaldi, Michele (2016). "A Formal definition of Big Data based on its essential Features". Library Review. 65:122-135.

[6] Hilbert, Martin. "Big Data for Development: A Review of Promises and Challenges. Development Policy Review". Mart inhilbert.net. Retrieved 7 October 2015

[7] "Data, data everywhere". The Economist. 25 February 2010. Retrieved 9 December 2012.

[8] Chen Qingbin, Reconstruction of the Teaching Model of College English Writing in the Big Data Era (in Chinese), Foreign Language Research, Vol.3, 2016 
[9] Wang Haixiao, Reform of College English Writing Teaching in Big Data Era (in Chinese), Modern Distance Education Research, 2014.

[10] Du Juan, Reform of College English Writing Teaching in Big Data Era (in Chinese), New Curriculum Research, 2017. 